Journal of Maternal and Child Health (2017), 2(2): 177-187

https://doi.org/10.26911/thejmch.2017.02.02.08

\title{
Risk Factors of Postpartum Hemorrhage in Bondowoso District, East Java
}

\author{
Ratna Puspitasari'), Uki Retno Budi Hastuti'), Bhisma Murti 1) \\ 1) Masters Program in Public Helath, Sebelas Maret University, Surakarta \\ 2) Departement of Obstetrics and Gynecology, Dr. Moewardi Hospital Surakarta
}

\begin{abstract}
Background: Postpartum hemorrhage is the leading cause of the maternal death worldwide. Postpartum hemorrhage accounted 20\% of all causes of maternal death in Bondowoso, East Java. This study aimed to examine the risk factors of postpartum hemorrhage.

Subjects and Method: This was an analytic observational study using case control design. The study was carried out at 5 community health centers, Bondowoso District, East Java, from March to May 2017. A sample of 120 study subjects were selected for this study by fixed disease sampling, consisting of 40 postpartum women with hemorrhage and 80 postpartum women without hemorrhage. The dependent variable was postpartum hemorrhage. The independent variables were family income, birth space, type of delivery, mother's middle upper arm circumference (MUAC), antenatal visit, and high-risk score card. The data were collected by a set of pre-tested questionnaire. Path analysis was employed for data analysis.

Results: Post partum bleeding was directly affected by birth space $<2$ years or $>10$ years $(b=3.03$; 95\% CI $=1.52$ to $4.55 ; \mathrm{p}<0.001)$, antenatal visit $\geq 4$ times $(\mathrm{b}=3.35 ; 95 \% \mathrm{CI}=1.82$ to $4.87 ; \mathrm{p}<$ o.001), High risk score $<2(b=2.18 ; 95 \% \mathrm{CI}=0.92$ to $3.44 ; \mathrm{p}=0.001)$, type of delivery $(\mathrm{b}=1.63 ; 95 \%$ $\mathrm{CI}=0.39$ to $2.87 ; \mathrm{p}=0.010)$. High-risk score card was affected by birth space $<2$ years or $>10$ years $(b=0.80 ; 95 \% \mathrm{CI}=0.32$ to $1.57 ; \mathrm{p}=0.041)$, family income $<\mathrm{Rp} 1,417,000(\mathrm{~b}=0.72 ; 95 \% \mathrm{CI}=-0.57$ to $1.49 ; \mathrm{p}=0.070)$, and antenatal visit $\geq 4(\mathrm{~b}=0.70 ; 95 \% \mathrm{CI}=-0.07$ to $1.48 ; \mathrm{p}=0.076)$. MUAC was affected by family income $\geq \mathrm{Rp} 1,417,000(\mathrm{~b}=0.67 ; 95 \% \mathrm{CI}=-0.08$ to $1.44 ; \mathrm{p}=0.083)$. Type of delivery (assisted) was affected by high-risk score card $<2(b=1.00 ; 95 \% \mathrm{CI}=0.22$ to $1.77 ; \mathrm{p}=0.011)$ and mother's MUAC $<23.5 \mathrm{~cm}(\mathrm{~b}=1.04 ; 95 \% \mathrm{CI}=0.20$ to $1.88 ; \mathrm{p}=0.015)$.

Conclusion: Post partum bleeding was directly affected by birth space, antenatal visit, high risk score, type of delivery. High-risk score card was affected by birth space, family income, and antenatal visit. MUAC was affected by family income. Type of delivery (assisted) was affected by high-risk score card and mother's MUAC.
\end{abstract}

Keywords: postpartum hemorrhage, risk factor

\section{Correspondence:}

Ratna Puspitasari. Masters Program in Public Helath, Sebelas Maret University, Surakarta Email: ratnapuspita1987@yahoo.co.id. Mobile: +6285791373311

\section{LATAR BELAKANG}

$\overline{\text { Kematian ibu merupakan indikator penting }}$ yang mencerminkan status kesehatan masyarakat. Makin tinggi Angka Kematian Ibu (AKI) maka derajat kesehatan dapat dikategorikan buruk dan belum berhasil dalam meningkatkan derajat kesehatan masyarakat (Kementrian Kesehatan RI, 2015). Sebagian besar kasus kematian ibu terjadi dalam waktu 24 jam setelah me- lahirkan dan perdarahan pasca persalinan merupakan salah satu penyebab langsung dari kematian ibu. Perdarahan pasca persalinan merupakan penyebab tak terduga dan penyebab tercepat kematian ibu di seluruh dunia (USAID, 2011).

Angka Kematian Ibu (AKI) di Indonesia pada tahun 2015 yaitu 305 per 100,000 kelahiran hidup. Kematian ibu di Indonesia masih didominasi oleh tiga 
penyebab utama kematian yaitu perdarahan, hipertensi dalam kehamilan, dan infeksi (Kemenkes RI, 2015). Berdasarkan data Dinas Kesehatan Provinsi Jawa Timur tahun 2014, Angka Kematian Ibu (AKI) di Provinsi Jawa Timur mencapai 93.52 per 100,000 kelahiran hidup. Angka ini mengalami penurunan dibandingkan tahun 2013 yang mencapai 97.39 per 100,o0o kelahiran hidup. Penyebab tingginya Angka Kematian Ibu (AKI) di Jawa Timur tahun 2014 disebabkan oleh perdarahan (25.57\%), preeklamsi/eklamsi (31.04\%), infeksi (6.17\%), jantung (12.35\%), penyebab lainnya (24. 87\%). Sedangkan penyebab Angka Kematian Ibu (AKI) tahun 2013 yaitu perdarahan (21. 81\%), pre eklamsi/eklamsi (36.29\%), infeksi (6.07\%), jantung (12.93\%), penyebab lainnya (22.90\%). Dilihat dari penyebab kematian ibu tahun 2013-2014 terjadi peningkatan pada faktor pendarahan, infeksi dan pre eklamsi atau eklamsi (Dinkes Provinsi Jawa Timur, 2014).

Angka Kematian Ibu (AKI) di Kabupaten Bondowoso mengalami peningkatan dalam tiga tahun terakhir. Angka Kematian Ibu (AKI) di Bondowoso pada tahun 2014 sejumlah 17 orang, pada tahun 2015 meningkat menjadi 19 orang, dan pada tahun 2016 meningkat kembali menjadi 20 orang. Penyebab tingginya Angka Kematian Ibu (AKI) di Kabupaten Bondowoso pada tahun 2016 yaitu perdarahan pasca persalinan 4 orang (20\%), pre eklamsi atau eklamsi 5 orang (25\%), infeksi 4 orang (20\%), penyebab lainnya yaitu dikarenakan CVA (5\%), serosis (5\%), abortus (5\%), GGK (5\%), syok hipovolemik (5\%), TBC (5\%), dan epilepsi (5\%) (Dinkes Kabupaten Bondowoso, 2016).

Berdasarkan data yang didapatkan dari Dinas Kesehatan Kabupaten Bondowoso, perdarahan pasca persalinan menjadi salah satu faktor yang menyebabkan tingginya Angka Kematian Ibu di Bondowoso tahun 2016. Kejadian perdarahan pasca persalinan yang terjadi di Kabupaten Bondowoso pada tiga tahun terakhir pada tahun 2014 sebanyak 235 orang, tahun 2015 mengalami penurunan menjadi 180 orang dan pada tahun 2016 mengalami peningkatan kembali menjadi 196 orang (Dinkes Kabupaten Bondowoso, 2016).

Banyak faktor risiko yang dapat meningkatkan terjadinya perdarahan pasca persalinan. Berdasarkan penelitian yang dilakukan Lumbantoruan et al., (2014) faktor risiko yang mempengaruhi kejadian perdarahan pasca persalinan yaitu umur, anemia, riwayat perdarahan sebelumnya, dan kunjungan ANC. Kunjungan ANC menjadi salah satu faktor risiko yang meningkatkan kejadian perdarahan pasca persalinan karena apabila ibu melakukan pelayanan ANC secara teratur dapat dilakukan deteksi dini terhadap kemungkinan adanya penyakit yang timbul pada masa kehamilan sehingga penyakit atau komplikasi yang ditemukan pada ibu dapat tertangani. Selain itu juga terdapat penelitian yang dilakukan Hidayah (2013) didapatkan hasil bahwa salah satu faktor risiko terjadinya perdarahan pasca persalinan adalah persalinan dengan tindakan.

Menurut Choe et al., (2016), salah satu faktor risiko yang mempengaruhi perdarahan pasca persalinan adalah pendapatan. Wanita dengan pendapatan rumah tangga lebih rendah memiliki risiko lebih tinggi terkena preeklampsia dan perdarahan pasca persalinan dibandingkan dengan wanita yang berpendapatan lebih tinggi. Berdasarkan penelitian yang dilakukan Mariza (2016) pendapatan keluarga yang rendah menyebabkan tidak tercukupinya kebutuhan gizi pada ibu, dan juga sosial ekonomi rendah menyebabkan ibu tidak mampu untuk melakukan ANC sehingga kemungkinan besar gejala anemia tidak terdeteksi. 
Journal of Maternal and Child Health (2017), 2(2): 177-187

https://doi.org/10.26911/thejmch.2017.02.02.08

Upaya penurunan AKI yang telah dilakukan yaitu penempatan bidan di desa, pemberdayaan keluarga dan masyarakat dengan menggunakan Buku Kesehatan Ibu dan Anak (KIA) dan dilaksanakannya Program Perencanaan Persalinan dan Pencegahan Komplikasi $\left(\mathrm{P}_{4} \mathrm{~K}\right)$ serta penyediaan fasilitas kesehatan Pelayanan Obstetri Emergensi Dasar (PONED) di Puskesmas dan Perawatan Obstetri Neonatal Emergensi Komprehensif (PONEK) di rumah sakit. Dinas Kesehatan Jawa Timur mencanangkan Program Gerakan Bersama Amankan Kehamilan (GEBRAK) pada tahun 2013. Program ini bertujuan untuk melakukan pendampingan bagi ibu hamil risiko tinggi yang dimulai saat kehamilan hingga masa nifas dan dengan adanya program ini diharapkan mampu mendeteksi secara dini komplikasi pada ibu hamil salah satunya adalah perdarahan pasca persalinan. Sejauh ini Laporan Dinas Kesehatan Bondowoso hanya sebatas jumlah kejadian perdarahan pasca persalinan, sementara faktor penyebab perdarahan pasca persalinan belum diungkap lebih jauh, sehingga perlu diteliti faktor apa saja yang mempengaruhi perdarahan pasca persalinan di Kabupaten Bondowoso tahun 2016.

Tujuan penelitian ini adalah untuk menganalisis pengaruh pendapatan keluarga, jarak kehamilan, jenis persalinan, ukuran lingkar lengan atas (LILA), frekuensi ANC,jumlah skor KSPR terhadap kejadian perdarahan pasca persalinan.

\section{SUBJEK DAN METODE}

\section{Desain Penelitian}

Metode penelitian pada penelitian ini adalah studi analitik observasional, dengan pendekatan desain case control. Penelitian dilaksanakan di enam Puskesmas di Kabupaten Bondowoso yaitu Puskesmas Grujugan, Puskemas Tamanan, Puskesmas Tlogosari, Puskesmas Tegalampel, Puskesmas
Wonosari, dan Puskesmas Tenggarang. Waktu pelaksanaan mulai bulan Maret Mei 2017.

\section{Populasi dan Sampel}

Populasi sasaran dalam penelitian adalah semua ibu yang melahirkan yang terdata di wilayah kerja Puskesmas Grujugan, Puskesmas Tamanan, Puskesmas Tlogosari, Puskesmas Tegalampel, Puskesmas Wonosari, dan Puskesmas Tenggarang Kabupaten Bondowoso tahun 2016. Populasi target dalam penelitian ini adalah semua ibu postpartum yang terdata di wilayah kerja Puskesmas Grujugan, Puskemas Tamanan, Puskesmas Tlogosari, Puskesmas Tegalampel, Puskesmas Wonosari, dan Puskesmas Tenggarang, Kabupaten Bondowoso tahun 2016.

Sampel dalam penelitian ini sebesar 120 subjek dengan menggunakan perbandingan 1:2 yaitu jumlah kelompok kontrol 2 kali (80) dari kelompok kasus (40). Teknik sampling yang akan digunakan dalam penelitian kuantitatif yaitu fixed disease sampling yaitu memastikan jumlah subjek penelitian yang cukup dalam kelompok berpenyakit (kasus) dan tidak berpenyakit (control) sehingga menguntungkan peneliti ketika prevalensi penyakit yang diteliti rendah (Murti, 2013).

\section{Variabel Penelitian}

Terdapat tujuh variabel dalam penelitian ini yang terdiri dari variabel dependen dan independen. Variabel dependen yaitu perdarahan pasca persalinan. Variabel independen yaitu pendapatan keluarga, jarak kehamilan, jenis persalinan, ukuran LILA ibu, frekuensi ANC, dan jumlah skor KSPR.

\section{Definisi Operasional Variabel}

Definisi operasional variabel pendapatan keluarga adalah jumlah penghasilan keluarga yang diterima tiap bulan; jarak kehamilan adalah jarak antara persalinan terakhir dengan kehamilan berikutnya; jenis persalinan adalah cara ibu melahirkan 
pada saat persalinan terakhir; ukuran LILA ibu adalah hasil pengukuran lingkar lengan atas ibu untuk melihat status gizi ibu hamil pada kehamilan yang terakhir; frekuensi ANC adalah frekuensi ibu melakukan pemeriksaan kehamilan ke tenaga kesehatan, minimal 4 kali yaitu 1 kali pada trimester I, 1 kali pada trimester II, dan 2 kali pada trimester III; jumlah skor pada KSPR adalah jumlah perhitungan pada Kartu Skor Poedji Rochjati yang dilakukan pada kehamilan ibu yang terakhir. Kejadian perdarahan pasca per-

Tabel 1. Karakteristik subjek penelitian salinan adalah pengeluaran darah setelah bayi lahir dengan jumlah lebih dari $500 \mathrm{ml}$. Pengumpulan data menggunakan kuesioner, catatan rekam medis (Medical $\mathrm{Re}^{-}$ cord). Analisis data menggunakan analisis jalur (path analysis) dengan STATA 13.

\section{HASIL}

Hasil penelitian menguraikan karakteristik subjek penelitian yang meliputi pendapatan keluarga, jarak kehamilan, jenis persalinan, ukuran LILA, frekuensi ANC, jumlah skor pada Kartu Skor Poedji Rochjati (KSPR).

\begin{tabular}{|c|c|c|c|c|}
\hline \multirow{2}{*}{ Karakteristik } & \multicolumn{2}{|c|}{ Kasus } & \multicolumn{2}{|c|}{ Kontrol } \\
\hline & $\mathbf{N}$ & $(\%)$ & $\mathbf{N}$ & $(\%)$ \\
\hline \multicolumn{5}{|c|}{ Pendapatan keluarga (rupiah) } \\
\hline$<\operatorname{Rp} 1,417,000$ & 27 & 67.5 & 36 & 45 \\
\hline \multicolumn{4}{|l|}{ Jarak kehamilan (tahun) } & 55 \\
\hline$<2$ atau $\geq 10$ & 30 & 75 & 22 & 27.5 \\
\hline$\geq 2$ atau $<10$ & 10 & 25 & 58 & 72.5 \\
\hline \multicolumn{5}{|l|}{ Jenis persalinan } \\
\hline Persalinan dengan tindakan & 28 & 70 & 24 & 30 \\
\hline Persalinan tanpa tindakan & 12 & 30 & 56 & 70 \\
\hline \multicolumn{5}{|l|}{ Ukuran LILA ibu } \\
\hline$<23.5 \mathrm{~cm}$ & 30 & 75 & 49 & 61.3 \\
\hline$\geq 23.5 \mathrm{~cm}$ & 10 & 25 & 31 & 38.8 \\
\hline \multicolumn{5}{|l|}{ Frekuensi ANC } \\
\hline$<4$ kali & 29 & 72.5 & 18 & 22.5 \\
\hline$\geq 4$ kali & 11 & 27.5 & 62 & 77.5 \\
\hline \multicolumn{5}{|l|}{ Jumlah skor pada KSPR } \\
\hline$\geq 2$ & 29 & 72.5 & 19 & 23.8 \\
\hline 2 & 11 & 27.5 & 61 & 76.3 \\
\hline
\end{tabular}

Tabel 1 menunjukkan bahwa pendapatan keluarga $\mathrm{Rp} \leq 1.417 .000,-$ mendominasi pada kelompok kasus sebanyak $67.5 \%$ sedangkan pendapatan keluarga $\geq \mathrm{Rp} 1,417,000$ mendominasi pada kelompok kontrol yaitu sebanyak 55\%. Jarak kehamilan <2 atau $\geq 10$ tahun mendominasi pada kelompok kasus sebanyak $75 \%$ dan jarak kehamilan $\geq 2$ atau <10 mendominasi kelompok kontrol sebanyak $72.5 \%$. Jenis persalinan dengan tindakan mendominasi pada kelompok kasus sebanyak 70\% dan jenis persalinan tanpa tindakan mendominasi pada kelompok kontrol sebanyak 70\%.
Ukuran LIL $\leq 23.5 \mathrm{~cm}$ mendominasi pada kelompok kasus sebanyak $75 \%$ sedangkan ukuran LILA $\geq 23.5 \mathrm{~cm}$ mendominasi kelompok kontrol sebanyak 61.3\%. Frekuensi ANC $\leq 4$ kali mendominasi pada kelompok kasus sebanyak 72.5\% sedangkan frekuensi ANC $\geq 4$ kali mendominasi pada kelompok kontrol sebanyak 77.5\%.

Jumlah skor pada KSPR $\geq 2$ mendominasi pada kelompok kasus sebanyak 72.5\% sedangkan jumlah skor pada KSPR 2 mendominasi pada kelompok kontrol sebanyak $76.3 \%$. 
Tabel 2 menyajikan analisis bivariat pengaruh pendapatan keluarga, jarak kehamilan, jenis persalinan, ukuran LILA, frekuensi ANC, jumlah skor pada Kartu Skor Poedji Rochjati (KSPR) ibu terhadap perdarahan pasca persalinan.

Hasil analisis menunjukkan bahwa ada hubungan yang signifikan antara pendapatan keluarga $(\mathrm{OR}=2.53$; $\mathrm{CI} 95 \%=1.14$ hingga $5.62 ; \mathrm{p}=0.020)$, jarak kehamilan $(\mathrm{OR}=7.90$; CI 95\% $=3.32$ hingga $18.83 ; \mathrm{p}<0.001)$, jenis

Tabel 2. Analisis bivariat pengaruh faktor risiko pendapatan keluarga, jarak kehamilan, jenis persalinan, ukuran lingkar lengan atas (LILA) ibu, frekuensi ANC, jumlah skor pada kartu skor Poedji Rochjati (KSPR) terhadap kejadian perdarahan pasca persalinan

\begin{tabular}{lcccc}
\hline \multirow{2}{*}{ Variabel Independen } & \multirow{2}{*}{ OR } & \multicolumn{2}{c}{ CI (95\%) } & \multirow{2}{*}{ p } \\
\cline { 3 - 4 } & & Batas Bawah & Batas Atas & 0.020 \\
Pendapatan keluarga & 2.53 & 1.14 & 5.62 & $<.83$ \\
Jarak kehamilan & 7.90 & 3.32 & 18.001 \\
Jenis persalinan & 5.44 & 2.37 & 4.46 & $<0.001$ \\
Ukuran LILA ibu & 1.89 & 0.81 & 21.67 & 0.134 \\
Frekuensi ANC & 9.08 & 3.80 & 20.08 & $<0.001$ \\
Jumlah skor pada KSPR & 8.46 & 3.56 & & $<0.001$ \\
\hline
\end{tabular}

Model analisis jalur yang dibuat oleh peneliti berdasarkan teori dicek/ dites kesesuaiannya dengan model hubungan variabel yang terbaik, yang dibuat berdasarkan data sampel yang dibuat peneliti. Gambar 1 persalinan $(\mathrm{OR}=5.44$; $\mathrm{CI} 95 \%=2.37$ hingga 12.46; $\mathrm{p}<0.001)$, ukuran LILA ibu (OR= 1.89; CI 95\%=0.81 hingga 4.42; $\mathrm{p}=0.134)$, frekuensi ANC (OR=9.08; CI $95 \%=3.80$ hingga $21.67 \mathrm{p}<0.001$ ), jumlah skor pada KSPR (OR=8.46; CI 95\%=3.56 hingga 20.08; $\mathrm{p}<0.001)$. Hasil analisis menunjukkan tidak ada hubungan antara ukuran LILA ibu (OR=1.89; CI 95\%= 0.81 hingga 4.42; $\mathrm{p}=0.134)$ terhadap perdarahan pasca persalinan. menunjukkan model struktural setelah dilakukan estimasi menggunakan STATA 13, sehingga didapatkan nilai seperti pada gambar tersebut.

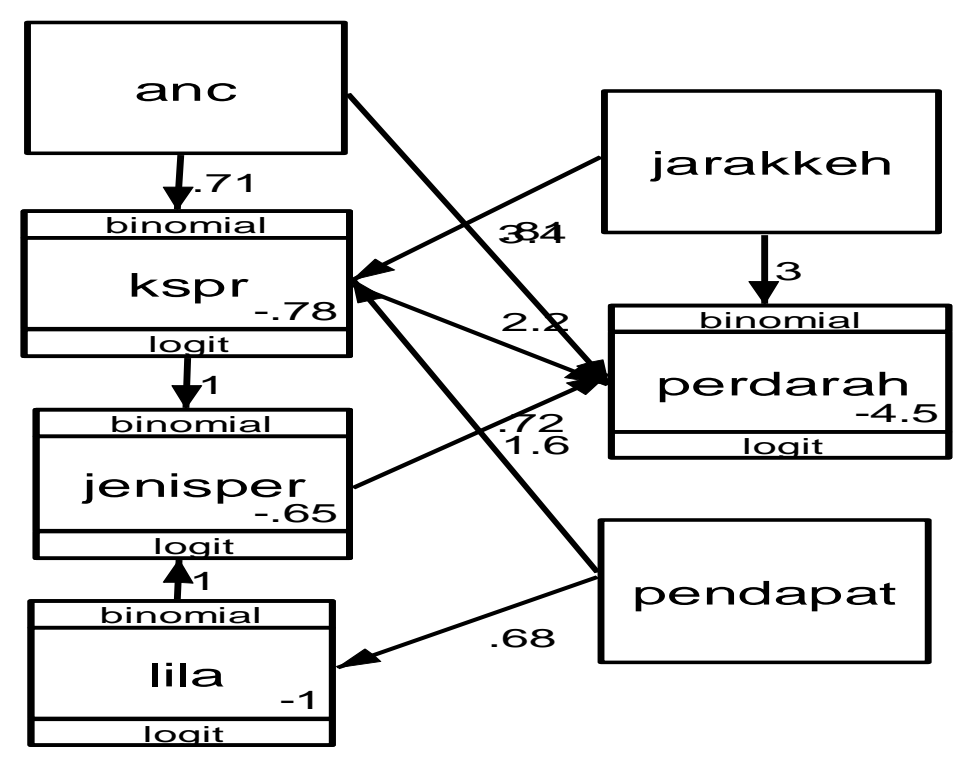

Gambar 1. Model struktural analisis jalur 
Indikator yang menunjukan kesesuaian model analisis jalur yaitu seperti pada Tabel 3. Perdarahan pasca persalinan di Kabupaten Bondowoso dipengaruhi langsung oleh jarak kehamilan, frekuensi ANC, jumlah skor KSPR dan jenis persalinan. Ibu dengan jarak kehamilan $<2$ tahun atau $>10$ tahun meningkatkan risiko perdarahan pasca persalinan $(b=3.03$; CI $95 \%=1.52$ hingga $4.55 ; \mathrm{p}<0.001)$. Ibu dengan fre- kuensi ANC <4 meningkatkan risiko perdarahan pasca persalinan $(\mathrm{b}=3.35$; CI $95 \%=$ 1.82 hingga $4.87 ; \mathrm{p}<0.001)$. Ibu dengan jumlah skor KSPR $\geq 2$ berisiko meningkatkan perdarahan pasca persalinan $(\mathrm{b}=2.18$; CI 95\%=0.92 hingga 3.44; $\mathrm{p}=0.001$ ). Ibu dengan jenis persalinan dengan tindakan berisiko meningkatkan perdarahan pasca persalinan $(b=1.63$; CI 95\%= 0.39 hingga $2.87 ; \mathrm{p}=0.010)$.

Tabel 3 Hasil model analisis jalur faktor risiko pendapatan keluarga, jarak kehamilan, jenis persalinan, ukuran lingkar lengan atas (LILA) ibu, frekuensi ANC, jumlah skor pada Kartu Skor Poedji Rochjati (KSPR) terhadap kejadian perdarahan pasca persalinan di Kabupaten Bondowoso

\begin{tabular}{|c|c|c|c|c|c|c|}
\hline \multirow[b]{2}{*}{$\begin{array}{c}\text { Variabel } \\
\text { Dependen }\end{array}$} & & \multirow[b]{2}{*}{ Variabel Independen } & \multirow[b]{2}{*}{ b } & \multicolumn{2}{|c|}{ CI (95\%) } & \multirow[b]{2}{*}{$\mathbf{p}$} \\
\hline & & & & $\begin{array}{l}\text { Batas } \\
\text { Bawah }\end{array}$ & $\begin{array}{l}\text { Batas } \\
\text { Atas }\end{array}$ & \\
\hline \multicolumn{7}{|c|}{ Pengaruh Langsung } \\
\hline $\begin{array}{l}\text { Perdarahan pasca } \\
\text { persalinan }\end{array}$ & $\leftarrow$ & $\begin{array}{l}\text { Jarak kehamilan }<2 \text { tahun atau } \\
\geq 10 \text { tahun }\end{array}$ & 3.03 & 1.52 & 4.55 & $<0.001$ \\
\hline $\begin{array}{l}\text { Perdarahan pasca } \\
\text { persalinan }\end{array}$ & $\leftarrow$ & Frekuensi ANC < 4 & 3.35 & 1.82 & 4.87 & $<0.001$ \\
\hline $\begin{array}{l}\text { Perdarahan pasca } \\
\text { persalinan }\end{array}$ & $\leftarrow$ & Jumlah skor KSPR $\geq 2$ & 2.18 & 0.92 & 3.44 & 0.001 \\
\hline $\begin{array}{l}\text { Perdarahan pasca } \\
\text { persalinan }\end{array}$ & $\leftarrow$ & $\begin{array}{l}\text { Jenis persalinan dengan } \\
\text { tindakan }\end{array}$ & 1.63 & 0.39 & 2.87 & 0.010 \\
\hline \multicolumn{7}{|c|}{ Pengaruh Tidak Langsung } \\
\hline Jumlah skor KSPR & $\leftarrow$ & $\begin{array}{l}\text { Jarak kehamilan } \leq 2 \text { tahun atau } \\
\geq 10 \text { tahun }\end{array}$ & 0.80 & 0.32 & 1.57 & 0.041 \\
\hline Jumlah skor KSPR & $\leftarrow$ & $\begin{array}{l}\text { Pendapatan keluarga } \\
<\text { Rp1.417.000 }\end{array}$ & 0.72 & -0.57 & 1.49 & 0.070 \\
\hline Jumlah skor KSPR & $\leftarrow$ & Frekuensi ANC <4 & 0.70 & -0.07 & 1.48 & 0.076 \\
\hline Ukuran LILA ibu & & $\begin{array}{l}\text { Pendapatan keluarga }<\mathrm{Rp} \\
1,417,000\end{array}$ & 0.67 & -0.08 & 1.44 & 0.083 \\
\hline Jenis persalinan & $\leftarrow$ & Jumlah skor KSPR <2 & 1.00 & 0.22 & 1.77 & 0.011 \\
\hline Jenis persalinan & $\leftarrow$ & Ukuran LILA <23.5 cm & 1.04 & 0.20 & 1.88 & 0.015 \\
\hline
\end{tabular}

Jumlah skor KSPR dipengaruhi oleh jarak kehamilan, pendapatan dan frekuensi ANC. Ibu dengan jarak kehamilan $<2$ tahun atau lebih $\geq 10$ tahun meningkatkan jumlah skor KSPR. Ibu dengan pendapatan keluarga $<\operatorname{Rp} 1,417$,ooo meningkatkan jumlah skor KSPR. Ibu dengan frekuensi ANC $\geq 4$ meningkatkan jumlah skor KSPR.

Ukuran LILA ibu dipengaruhi pendapatan keluarga. Ibu yang pendapatan keluarga < $\operatorname{Rp~1,417,000~meningkatkan~}$ risiko KEK. Jenis persalinan ibu dipenga- ruhi oleh jumlah skor KSPR dan ukuran LILA ibu. Ibu dengan jumlah skor KSPR $\geq 2$ meningkatkan risiko jenis persalinan dengan tindakan. Ibu dengan ukuran LILA $<23.5 \mathrm{~cm}$ meningkatkan risiko KEK.

\begin{tabular}{l}
\hline PEMBAHASAN \\
\hline 1. Pengaruh Pendapatan Keluarga \\
Terhadap Kejadian Perdarahan \\
Pasca Persalinan
\end{tabular}

Hasil analisis menunjukkan bahwa terdapat pengaruh tidak langsung antara pendapat- 
Journal of Maternal and Child Health (2017), 2(2): 177-187

https://doi.org/10.26911/thejmch.2017.02.02.08

an keluarga terhadap kejadian perdarahan pasca persalinan. Pendapatan keluarga merupakan jumlah penghasilan riil dari seluruh anggota rumah tangga yang digunakan untuk memenuhi kebutuhan bersama maupun perorangan dalam rumah tangga. Menurut Peraturan Guberenur Jawa Timur Nomor 72 tahun 2016 tentang upah minimum pada 38 Kabupaten/ Kota di Jawa Timur tahun 2016, menetapkan upah minimum Kabupaten Bondowoso tahun 2016 sebesar Rp 1,417,00o. Pendapatan keluarga sangat berpengaruh terhadap konsumsi makanan sehari-hari. Apabila pendapatan rendah maka makanan yang dikonsumsi tidak mempertimbangkan nilai gizi. Ibu hamil pendapatan rendah juga akan mempengaruhi kemampuan ibu untuk melakukan ANC. Apabila ANC dilakukan secara teratur maka tanda bahaya dapat terdeteksi sejak awal (Choe et al., 2016)

Hasil penelitian ini tidak sejalan dengan penelitian Choe et al., (2016) yang menyimpulkan bahwa pendapatan keluarga berhubungan secara signifikan terhadap kejadian perdarahan pasca persalinan. Pendapatan terbukti sangat berpengaruh terhadap kondisi kesehatan fisik dan psikologis ibu hamil. Ibu hamil dengan pendapatan tinggi otomatis akan mendapatkan kesejahteraan fisik dan psikologi yang baik pula. Status gizi pun akan meningkat karena nutrisi yang didapatkan berkualitas, selain itu ibu tidak akan terbebani secara psikologis mengenai biaya persalinan dan pemenuhan kebutuhan sehari-hari setelah bayinya lahir. Kurangnya pendapatan keluarga menyebabkan kurangnya jumlah dan kualitas makanan yang dikonsumsi ibu perhari yang berdampak pada penurunan status gizi. Penurunan status gizi yang umum terjadi pada perempuan terutama pada ibu hamil adalah anemia. Sumber makanan untuk mencegah anemia umum- nya berasal dari sumber protein yang lebih mahal dan sulit terjangkau oleh mereka yang berpenghasilan rendah. Hal tersebut tersebut memperbesar risiko anemia pada remaja dan ibu hamil serta memperberat kesakitan pada ibu dan pada bayi baru lahir dan anemia juga berperan terhadap tingginya angka kematian ibu (Frass, 2014).

Menurut penelitian yang dilakukan Mariza (2016) selain mempengaruhi kebutuhan gizi pada ibu, pendapatan keluarga yang rendah berpengaruh pada kemampuan ibu untuk melakukan ANC sehingga kemungkinan besar gejala anemia tidak terdeteksi. Keadaan $\mathrm{Hb}$ yang turun sampai $<11$ gr\% akan membuat kontraksi uterus lemah (atonia uteri) sehingga berpotensi mengalami perdarahan dan menyebabkan morbiditas dan mortalitas ibu dan anak.

\section{Pengaruh Jarak Kehamilan Ter- hadap Kejadian Perdarahan Pasca Persalinan.}

Hasil analisis menunjukkan bahwa terdapat pengaruh langsung antara jarak kehamilan terhadap kejadian perdarahan pasca persalinan dan secara statistik signifikan $(b=$ 3.03; CI 95\% $=1.52$ hingga 4.55; $\mathrm{p}<0.001$ ). Rahim atau uterus sebenarnya sudah pulih kembali 6 bulan setelah melahirkan akan tetapi fungsinya belum bekerja secara maksimal dan persalinan yang berturutturut dalam jangka waktu yang singkat akan mengakibatkan kontraksi uterus menjadi kurang baik (Rochjati, 2012).

Hasil penelitian ini sejalan dengan penelitian Hazmi (2013) yang menyimpulkan bahwa jarak kehamilan beresiko memiliki peluang 2,853 kali untuk mengalami perdarahan pasca persalinan.

Jarak kehamilan yang pendek secara langsung akan memberikan efek terhadap kesehatan wanita maupun kesehatan janin yang dikandungnya. Seorang wanita setelah bersalin membutuhkan waktu 2 sampai 3 tahun untuk memulihkan tubuhnya dan 
mempersiapkan diri untuk kehamilan dan persalinan berikutnya. Bila jarak kehamilan terlalu dekat, rahim yang masih belum pulih benar akibat persalinan sebelumnya belum bisa memaksimalkan pembentukan cadangan makanan bagi janin dan untuk ibu sendiri. Akibatnya akan berdampak tidak baik bagi ibu maupun bayinya. Bagi ibu sendiri meningkatkan resiko terkena anemia akut. Ibu hamil yang terkena anemia akut akan meningkatkan resiko terhadap komplikasi kehamilan, bayi terlahir prematur, resiko perdarahan saat persalinan dan resiko terburuk yaitu keguguran (Rochjati, 2012).

\section{Pengaruh Jenis Persalinan Ter- hadap Kejadian Perdarahan Pasca Persalinan}

Hasil analisis menunjukkan bahwa terdapat pengaruh langsung antara jenis persalinan terhadap kejadian perdarahan pasca persalinan dan secara statistik signifikan. Persalinan tindakan dilakukan untuk membantu proses persalinan yang mengalami penyulit, sehingga dapat mengurangi risiko kematian ibu dan bayi. Namun persalinan dengan tindakan memberikan dampak kesakitan pada ibu dan bayi.

Hasil penelitian ini dihasilkan (OR= 1.63; CI 95\%=0.39 hingga 2.87; $\mathrm{p}=0.010$ ). Hasil penelitian ini sejalan dengan penelitian yang dilakukan Hidayah (2013) yang menyimpulkan bahwa persalinan dengan tindakan memiliki risiko 0.84 kali untuk mengalami perdarahan postpartum dibandingkan ibu bersalin tanpa tindakan persalinan. Persalinan tindakan merupakan salah satu faktor risiko terjadinya perdarahan postpartum. Persalinan tindakan diantaranya adalah persalinan tindakan pervaginam yaitu dengan vakum, forsep, episiotomi ataupun dengan oksitosin drip. Tindakan pada persalinan baik vaginam maupun abdominal dapat menyebabkan trauma baik pada ibu maupun pada bayinya. Berdasarkan penelitian yang dilakukan Khireddine et al., (2013) menemukan bahwa induksi persalinan secara independen terkait dengan risiko perdarahan postpartum berat pada ibu melahirkan yang berisiko rendah.

Menurut penelitian yang dilakukan Driessen et al., (2011) faktor risiko yang terkait dengan perdarahan postpartum salah satunya yaitu episiotomi. Stimulasi dengan oksitosin drip dapat merangsang timbulnya kontraksi uterus yang belum berkontraksi dan meningkatkan kekuatan serta frekuensi kontraksi pada uterus yang sudah berkontraksi. Stimulasi oksitosin drip dengan tujuan akselerasi pada dosis rendah dapat meningkatkan kekuatan serta frekuensi kontraksi, tetapi pada pemberian dengan dosis tinggi dapat menyebabkan tetania uteri dan terjadi trauma jalan lahir ibu yang luas dan menimbulkan perdarahan serta inversio uteri.

Stimulasi oksitosin drip dengan tujuan induksi oksitosin drip menyebabkan terjadinya stimulasi berlebihan kepada uterus sehingga mengalami overdistensi (peregangan uterus secara berlebihan) dan menyebabkan terjadinya hipotonia setelah persalinan (Hidayah, 2013).

\section{Pengaruh Ukuran LILA Ibu Ter- hadap Kejadian Perdarahan Pasca Persalinan}

Hasil analisis menunjukkan bahwa terdapat pengaruh tidak langsung antara ukuran LILA Ibu terhadap kejadian perdarahan pasca persalinan dan secara statistik tidak signifikan. LILA merupakan salah satu pilihan untuk penentuan status gizi ibu hamil. Pengukuran LILA adalah suatu cara untuk mengetahui resiko Kekurangan Energi Kronis (KEK) pada wanita usia subur (WUS). Ambang batas LILA WUS dengan risiko KEK di Indonesia adalah 23.5 cm. Apabila ukuran kurang dari $23.5 \mathrm{~cm}$ atau dibagian merah pita LILA, artinya 
wanita tersebut mempunyai risiko KEK. Gizi kurang pada ibu hamil dapat menyebabkan resiko dan komplikasi pada ibu antara lain anemia, perdarahan, berat badan ibu tidak bertambah secara normal dan terkena penyakit infeksi sehingga akan meningkatkan kematian ibu (Kemenkes, 2013).

Berdasarkan penelitian yang dilakukan Novyriana et al., (2016) didapatkan hasil ada hubungan antara Lingkar Lengan Atas dengan kejadian anemia. Hemoglobin sangat dibutuhkan oleh tubuh manusia untuk berbagai metabolisme sel dalam mengangkut $\mathrm{O}_{2}$ ke seluruh tubuh. Kondisi yang dikhawatirkan adalah kondisi disaat setelah melahirkan. Organ uterus memerlukan kontraksi yang kuat pada saat persalinan, menghentikan perdarahan akibat lepasnya plasenta dari perlekatannya di permukaan dalam rahim (endometrium) yang luas selama kehamilan dan sesudah persalinan untuk penegecilan (involusi) uterus. Keadaan $\mathrm{Hb}$ yang turun sampai < 11 gr\% akan membuat kontraksi uterus lemah (atonia uteri) sehingga berpotensi mengalami perdarahan dan menyebabkan morbiditas dan mortalitas ibu dan anak. Penelitian yang dilakukan Frass (2014) didapatkan hasil terdapat hubungan antara kadar $\mathrm{Hb}<11$ gr\% dengan kejadian perdarahan pasca persalianan, dimana anemia akan menyebabkan kontraksi uterus berkurang (atonia uetri) sehingga kejadian perdarahan dapat terjadi pada ibu bersalin.

\section{Pengaruh Frekuensi ANC Ter- hadap Kejadian Perdarahan Pasca Persalinan}

Hasil analisis menunjukkan bahwa terdapat pengaruh langsung antara frekuensi ANC terhadap kejadian perdarahan pasca persalinan dan secara statistik signifikan $(b=3.35$; CI 95\%= 1.82 hingga 4.87; $\mathrm{p}<$ 0.001). Kunjungan ANC dilakukan untuk pemantauan dan pengawasan kesejahtera- an ibu dan anak. Kunjungan ANC minimal dilakukan empat kali selama kehamilan yaitu sampai dengan kehamilan trimester pertama (<14 minggu) satu kali kunjungan, dan kehamilan trimester kedua (14-28 minggu) satu kali kunjungan dan kehamilan trimester tiga (28-36 minggu sampai lahir) dua kali kunjungan.

Hasil penelitian ini sesuai dengan penelitian yang dilakukan Aeni (2012) dimana pemeriksaan antenatal yang tidak lengkap meningkatkan risiko kematian ibu hingga 7.86 kali $(\mathrm{OR}=4.57 ; \mathrm{CI}=1.49$ hingga 4.13; $\mathrm{p}=0.008$ ). Ibu yang melakukan ANC $<4$ kali berisiko mengalami kematian 4.57 kali lebih besar dari pada ibu yang teratur melakukan pemeriksan ANC. Ibu yang melakukan ANC $\geq 4$ kali cenderung lebih banyak mengetahui informasi tentang kehamilan, persalinan dan nifas serta lebih memperhatikan kesehatan misalnya dalam memudahkan diagnosa secara dini dan didapatkan penanganan yang berkelanjutan untuk mempersiapkan langkah lebih lajut. Apabila ibu melakukan pelayanan ANC secara teratur dapat dilakukan deteksi dini terhadap kemungkinan adanya penyakit yang timbul pada masa kehamilan sehingga penyakit atau komplikasi yang ditemukan pada ibu dapat tertangani. Sebagian besar ibu dalam penelitiatelah melakukan ANC $\geq 4$ kali karena peran tenaga kesehatan sudah sangat berperan dengan baik dalam memberikan KIE tentang pentingnya pemeriksaan kehamilan sehingga masyarakat memahami pentingnya ANC saat hamil.

\section{Pengaruh Jumlah Skor KSPR Ibu Terhadap Kejadian Perdarahan Pasca Persalinan}

Hasil analisis menunjukkan bahwa terdapat pengaruh langsung antara jumlah skor KSPR terhadap kejadian perdarahan pasca persalinan $(b=2.18$; CI 95\%= 0.92 hingga 3.44; $\mathrm{p}=0.001)$. Deteksi dini risiko tinggi 
pada ibu hamil dapat dilakukan melalui Kartu Skor Pudji Rochyati yang ada di dalam buku KIA. Skreening ibu hamil dilakukan empat kali selama kehamilan yaitu satu kali pada kehamilan trimester pertama, satu kali pada kehamilan trimester kedua, dan dua kali pada kehamilan trimester ketiga. Kartu Skor Poedji Rochjati terdiri dari 28 faktor risiko yang dibagi menjadi 3 kelompok faktor risiko. Tujuan utama dilakukan penapisan faktor risiko adalah untuk mendeteksi wanita yang mempunyai risiko tinggi untuk mengalami komplikasi kehamilan, guna dirujuk ke tingkat pelayanan yang lebih tinggi. Faktor risiko adalah kondisi pada ibu hamil yang dapat menyebabkan kemungkinan risiko bahaya terjadinya komplikasi pada persalinan yang dapat menyebabkan kematian atau kesakitan pada ibu dan bayinya (Rochjati, 2012).

Hasil penelitian ini sesuai dengan penelitian yang dilakukan Widarta et al., (2015) didapatkan hasil bahwa seluruh kasus kematian maternal mengandung unsur faktor risiko dalam KSPR dan faktor empat terlambat. Empat terlambat meliputi kehamilan terlalu muda, usia yang terlalu tua untuk hamil, jarak kehamilan terlalu dekat dan kehamilan terlalu banyak. Wanita yang melahirkan anak pada usia kurang dari 20 tahun atau lebih dari 35 tahun menjadi faktor risiko terjadinya perdarahan pasca persalinan. Hal ini disebabkan pada usia kurang 20 tahun fungsi reproduksi seorang wanita belum berkembang dengan sempurna, sedangkan pada usia diatas 35 tahun fungsi reproduksi seorang wanita sudah mengalami penurunan dibandingkan fungsi reproduksi normal sehingga kemungkinan terjadinya pasca persalinan lebih besar. Kehamilan Risiko sangat tinggi merupakan kelompok faktor risiko terbanyak yang berisiko menyebabkan kematian maternal. Jumlah skor sama atau lebih 12 dengan kode warna merah, ibu hamil dengan resiko ganda atau lebih yang dapat mengancam nyawa ibu atau janin, rencana bersalin hanya boleh ditolong oleh dokter dan tempat persalinan di rumah sakit. Penyebab komplikasi persalinan yang tidak langsung adalah kondisi kesehatan yang buruk pada saat kehamilan atau melahirkan sebelumnya, yang akhirnya dapat menyebabkan kematian ibu terutama di negara-negara berkembang.

Berdasarkan hasil penelitian, dapat disimpulkan bahwa perdarahan pasca persalinan dipengaruhi oleh jarak kehamilan, frekuensi ANC, jumlah skor KSPR, dan jenis persalinan. Jumlah skor KSPR dipengaruhi oleh jarak kehamilan, pendapatan keluarga, dan frekuensi ANC. Ukuran LILA ibu dipengaruhi oleh pendapatan keluarga. Jenis persalinan dipengaruhi oleh jumlah skor KSPR dan ukuran LILA ibu.

\section{REFERENCE}

Choe S, Min H, Cho S (2016). The Income Based Disparities In Preeclampsia And Postpartum Hemorrhage: A Study Of The Korean National Health Insurance Cohort Data From 2002 To 2013, Spinger Open Journal 5 (895).

Dinkes Provinsi Jawa Timur (2014). Profil Kesehatan provinsi Jawa Timur Tahun 2014. Jawa Timur.

Dinkes Kabupaten Bondowoso (2016). Data Perdarahan Pasca Persalinan Tahun 2014, 2015, 2016. Bondowoso

Dinkes Kabupaten Bondowoso (2016). Data Kematian Ibu Tahun 2014, 2015, 2016. Bondowoso.

Driessen M, Colle M, Tharaux, C (2011). Postpartum Hemorrhage Resulting From Uterine Atony After Vaginal Delivery: Factors Associated With Severity.

Fatkhiyah N (2015). Motivasi, Kualitas Supervisi Dan Kepatuhan Bidan Dalam 
Mendeteksi Preeklampsia, Jurnal Kesehatan Masyarakat 10 (2): 195-202.

Fransisca S (2010), Perdarahan Postpartum

(Tesis), Universitas Wijaya Kusuma Surabaya.

Frass K (2014). Postpartum Hemorrhage Is Related To The Hemoglobin Levels At Labor: Observational Study, Alexandria Journal of Medicine 51: 333-337.

Friyandini F, Lestari Y, Utama B (2015)

Hubungan Kejadian Perdarahan Postpartum dengan Faktor Risiko Karakteristik Ibu di RSUP Dr. M. Djamil Padang pada Januari 2012-April 2013, Jurnal Kesehatan Andalas 4(3): $850-855$.

Hazmi S (2013). Faktor-Faktor Yang Mempengaruhi Kejadian Perdarahan Postpartum Di RSUD Panembahan Senopati (Tesis). Yogyakarta.

Hidayah F (2013). Faktor-Faktor Risiko Yang Mempengaruhi Kejadian Perdarahan Postpartum Primer Pada Ibu Bersalin Di RSUD Panembahan Senopati Bantul-DIY Tahun 2012 (Tesis). Yogyakarta.

Kemenkes RI (2012). Profil Kesehatan Indonesia Tahun 2012. Jakarta.

Kemenkes RI (2015). Profil Kesehatan Indonesia, Jakarta.

Khireddine I, Ray C, Dupont C, Rudigoz R, Colle, Tharaux $C$ (2013). Induction of Labor and Risk of Postpartum Hemorrhage in Low Risk Parturients, Plos One Journal 8(1): 143-147.

Lumbantoruan M, Wandra T, dan Anita S, 2014, Faktor-Faktor Yang Berhubungan Dengan Kejadian Perdarahan Post Partum Di Rumah Sakit Umum Daerah Kabupaten Aceh Tamiang Tahun 2014, Jurnal Reproductive Health 1 (1): $1-5$

Mariza A (2016). Hubungan Pendidikan Dan Sosial Ekonomi Dengan Kejadian Anemia Pada Ibu Hamil Di BPS T
Yohan Way Halim Bandar Lampung Tahun 2015. Jurnal Kesehatan Holistik 1(1): 1-4.

Murti B (2013). Desain dan Ukuran Sampel untuk Penelitian Kuantitatif dan Kualitatif di Bidang Kesehatan, Yogyakarta. Gajah Mada University Pres.

Novyriana E, Rahmadhani W, Zuhroh S (2016). Hubungan Lingkar Lengan Atas Dengan Kejadian Anemia Dalam Kehamilan, Jurnal Ilmiah Kesehatan Keperawatan 12(2): 45-48.

Rocjati P (2012). Skrining Antenatal Pada Ibu Hamil. Pusat Safe Mother HoodLab/SMF Obgyn RSU Dr. Sutomo, Fakultas Kedokteran UNAIR Surabaya.

Siswanto E (2011). Faktor-Faktor Penolong Persalinan (Bidan) dengan kejadian Perdarahan Paska Persalinan (Tesis), Universitas Diponegoro, Semarang.

Syafneli, Masyuni S (2010). Analisis Faktor-Faktor yang Berhubungan dengan Perdarahan Postpartum Primer (Tesis), Rokan Hulu.

Tako T, Ujjiga A, Ochi E (2014) Risk Factors Associated With Postpartum Haemorrhage at Juba Teaching Hospital, South Sudan Medical Journal 7 (3): 145-148.

USAID (2011). Prevention And Treatment Of Postpartum Hemorrhage At The Community Level: A Guide For Policy Makers, Health Care Providers, Donors, Community Leaders, And Program Managers, 2nd edition, Baltimore.

Widarta G, Laksana M, Sulistyono A (2015) Deteksi Dini Risiko Ibu Hamil dengan Kartu Skor Poedji Rochjati dan Pencegahan Faktor Empat Terlambat, Jurnal Obstetri \& Ginekologi 23(1). 